\title{
The first record of Argiope lobata (Pallas, 1772) (Aranei: Araneidae) for Tyumenskaya Oblast in West Siberia, Russia
}

\section{Первая находка Argiope lobata (Pallas, 1772) (Aranei: Araneidae) в Тюменской области (Западная Сибирь, Россия)}

\author{
V.I. Kapitonov, O.A. Kapitonova \\ В.И. Капитонов, О.А. Капитонова
}

Tobolsk Complex Scientific Station of the Ural Branch RAS, Acad. Yuriua Osipova Str. 15, Tobolsk 626152 Russia. E-mail: KapitonovVI@tobscience.ru.

Тобольская комплексная научная станция УрО РАН, ул. акад. Юрия Осипова 15, Тобольск 626152 Россия. Е-mail: KapitonovVI@tobscience.ru.

Key words: Argiope lobata, Lobed Argiope, spiders, Tyumenskaya Oblast, West Siberia.

Ключевые слова: Argiope lobata, аргиопа дольчатая, пауки, Тюменская область, Западная Сибирь.

Abstract. A female of Argiope lobata (Pallas, 1772) collected in August 2017 near Pervomaiskii village in Vagayskii District is first record of the species for Tyumenskaya Oblast in West Siberia, Russia. This is the northernmost record of the species which is limited to the southern taiga forests and aspen-birch subtaiga forests.

Резюме. Приведены сведения о первой находке Argiope lobata (Pallas, 1772) в Тюменской области. Одна самка отловлена в августе 2017 года в окрестностях п. Первомайский (Вагайский район). Указанное местонахождение вида располагается на стыке южно-таёжных и подтаёжных осиново-берёзовых лесов и является самой северной за пределами основного ареала.

The orb-weaver spider Argiope lobata (Pallas, 1772) is one of two representatives of the genus Argiope found in the fauna of Russia [Mikhailov, 2013; Tiunov, Esyunin, 2015]. This species is widespread in the Old World: Southern Europe to Central Asia and China, northern Africa, South Africa, Israel, India, from Myanmar to New Caledonia and northern Australia [World Spider Catalog, 2020].

On the territory of Russia, Argiope lobata is found in the southern regions mainly within the steppe and forest-steppe natural zones from Crimea to Lake Baikal [Esyunin, Efimik, 1996; Marusik, Kovblyuk, 2011, Kovblyuk et al., 2015; Tiunov, Esyunin, 2015; Tiunov, Turaeva, 2015]. Until the 70s of the last century, the northern border of the distribution of the species in the European part of Russia passed approximately N 52 ${ }^{\circ}$ [Tyshchenko, 1971]. In subsequent years, Lobed Argiope was noted significantly north of the indicated latitude on the territory of Tatarstan [Bespyatykh, 2016], Tul'skaya Oblast [Mikhailov, Panov, 2014] and Chuvashia [Borisova, 2016]. The last location of the species is the most northern and is located in a forest zone near $\mathrm{N} 56^{\circ}$.

In the Asian part of Russia, Argiope lobata was found in the Altajskii Krai and the Novosibirskaya Oblast [Azarkina, Trilikauskas, 2012; Azarkina et al., 2018], and there is also one find in the Irkutskaya Oblast near Lake
Baikal [Tiunov, Esyunin, 2015]. All known locations of species in the Asian part of the area do not go beyond N $54^{\circ}$.

During the expedition in August 2017, for the first time in the Tyumenskaya Oblast we discovered Lobed Argiope. Label data: 1 female, Russia, Tyumenskaya Oblast, Vagayskii Distr., $1.5 \mathrm{~km}$ southeast of the village Pervomayskii (57²3'24" N, 6904'09" E). 16.VIII.2017. On the dry gramineous-herbous meadow on the left high bank of the River Vagai. Collected: V.I. Kapitonov, O.A. Kapitonova. Defined by A.N. Sozontov. The material is stored in the zoological collection of the Tobolsk Complex Scientific Station of the Ural Branch of the Russian Academy of Sciences (Tobolsk).

The location of the species in the Tyumen Area is located at the turn of the southern taiga and subtaiga small-leaved (aspen-birch) forests and is currently the most northern outside the main range. There are no large settlements and transport highways in the catching area of the Lobed Argiope, and it is unlikely that the spider will accidentally drift because of human activities. Apparently, the emergence of Argiope lobata in the forest zone is associated with a natural expansion of the species area to the north against the background of the global climate changes. The valleys of medium and large rivers flowing meridionally can serve as an ecological corridor for the distribution of southern species in the northern direction.

\section{Acknowledgments}

The authors are grateful to A.N. Sozontov (Institute of Plant and Animal Ecology, Ural Branch of the Russian Academy of Sciences, Yekaterinburg) for help in identifying of the collected material.

\section{References}

Azarkina G.N., Lyubechanskii I.I., Trilikauskas L.A., Dudko R.Y., Bespalov A.N., Mordkovich V.G. 2018. A check-list and 
zoogeographic analysis of the spider fauna (Arachnida: Aranei) of Novosibirsk Area (West Siberia, Russia) // Arthropoda Selecta. Vol.27. No.1. P.73-93.

Azarkina G.N., Trilikauskas L.A. 2012. Spider fauna (Aranei) of the Russian Altai, part I: families Agelenidae, Araneidae, Clubionidae, Corinnidae, Dictynidae and Eresidae // Evraziatskii entomologicheskii zhurnal. Vol.11. No.3. P.199208 .

Bespyatykh A.V. 2016. [Lobed Argiope - Argiope lobata (Pallas, 1772)] // Krasnaya kniga Respubliki Tatarstan (zhivotnye, rasteniya, griby). Izdanie 3. Kazan: Idel-Press. P.150-151. [In Russian].

Borisova N.V. 2016. [To the knowledge of the fauna of spiders (Arachnida, Aranei) of the Transvolga region within the Chuvash Republic] // Trudy Mordovskogo gosudarstvennogo prirodnogo zapovednika imeni P.G. Smidovicha. No.17. P.25-34. [In Russian].

Esyunin S.L., Efimik V.E. 1996. Catalogue of the spiders (Arachnida, Aranei) of the Urals // Mikhailov K.G. (Ed.). M.: KMK Scientific Press Ltd. 229 p.

Kovblyuk N.M., Gnelitsa V.A., Nadolny A.A., Kastrygina Z.A., Kukushkin O.V. 2015. [Spiders (Arachnida: Aranei) of the Karadag Natural Reserve] // Ekosistemy. No.3. P.3-288. [In Russian].
Marusik Yu.M., Kovblyuk N.M. 2011. [Spiders (Arachnida, Aranei) of Siberia and Russian Far East]. M.: KMK Press. 344 p. [In Russian].

Mikhailov K.G. 2013. The spiders (Arachnida: Aranei) of Russia and adjacent countries: a non-annotated checklist // Arthropoda Selecta. Suppl. No.3. P.1-262.

Mikhailov K.G., Panov E.N.2014. [Lobed Argiope moves north] // Priroda. No.7. P.73-78. [In Russian].

Tiunov A.V., Esyunin S.L. 2015. Orb-Weaver Spiders of the Genus Argiope (Aranei, Araneidae) from Russia and Central Asia // Entomological Review. Vol.95. No.1. P.99-107.

Tiunov A.V., Turaeva A.S. 2015. [The fauna of orb weaver spiders of the family Araneidae of Western Siberia] // Programma i materialy mezhdunarodnoj nauchnoj konferencii, posvyashchyonnoj 50-letiyu Zoologicheskogo muzeya im. M.I. Globenko Tavricheskoj akademii Krymskogo federalnogo universiteta im. V.I. Vernadskogo (Simferopol, 16-18 sentyabrya 2015 g.). Simferopol. P.120-121. [In Russian].

Tyshchenko V.P. 1971. [The identification guide to spiders of the European part of the USSR]. Leningrad: Nauka Publ. 281 p. [In Russian].

World Spider Catalog. 2020. World Spider Catalog. Version 21.0. Natural History Museum Bern, online at http://wsc.nmbe.ch, accessed on 31.01.2020. doi: 10.24436/2.

Поступила в редакцию 17.2 .2020 